\title{
Bos Frontalis (Mithun): A Flagship Semi-Domesticated Mammal and Its Potential For 'Mithun Husbandry' Development in Arunachal Pradesh, India
}

\author{
Shivaji Chavan ${ }^{1 *}$, Mothilal Yuvaraja ${ }^{2}$ and Hirendra Nath Sarma ${ }^{2}$ \\ ${ }^{1}$ Department of Zoology, School of Life Sciences, Swami Ramanand Teerth Marathwada University, India \\ ${ }^{2}$ Centre with Potential for Excellence in Biodiversity, Rajiv Gandhi University, India
}

Received: 眥 July 25, 2018; Published: 制 August 06, 2018

*Corresponding author: Shivaji Chavan, Department of Zoology, School of Life Sciences, Swami Ramanand Teerth Marathwada University, Nanded-431606, Maharashtra State, India

\begin{abstract}
Objective: To determine the current status and importance of implementation of rapid action plan for scientific rearing of ruminant bovine Bos frontalis in North East especially in Arunachal Pradesh.

Study Outline and Methods: In year 2017 formal structured and semi-structured interviews of local people were conducted to gather the information. Based on the information some models and suggestions for development of Mithun Husbandry are suggested as concrete measures, instead of its free range rearing or partial domestication.

Results: The Mithun have been proved as untamed potential of North East India but without any major action plan for its prevention from steady extinction. Some of the possible measures for domestication of Mithun are suggested to boost the economy of locals and India in Total.

Conclusion: Mithun is an untamed potential animal that need to be explored by scientific domestication before its slow and steady extinction in progress from NE states of India. Mithun popular name of Bos frontalis a hybrid ruminant bovine developed some 8000 years back still remained in semi-domesticated conditions and it is being used in all major four states of North East states India as a rich quality source of animal proteins in the beef form. Comparatively very scanty measures have been taken for its domestication in scientific and sustainable way that is possible by Mithun Husbandry development in large scale in the North East states. The Mithun have been proved as untamed potential of North East India but without any major action plan for its prevention from steady extinction. Some of the possible measures for domestication of Mithun are suggested to boost the economy of locals and India in Total.
\end{abstract}

Keywords: Bos Frontalis; Mithun; Arunachal Pradesh; India

\section{Introduction}

Bos frontalis commonly named as 'Mithun' is a semidomesticated Mammal distributed in about 53,000 Km2 area in North-East India including Himalayan slopes in Arunachal Pradesh, Nagaland, Manipur, Mizoram and Myanmar in special. It is data deficient for its population in Wild and in the entire region of its distributional range. It is grouped under vulnerable species of Mammals in India (IUCN, 2017). In1987 it has been declared as State animal of Arunachal Pradesh under the name 'Mithun'. It is semi-domesticated (reared) in 13 districts out of 16 districts of
Arunachal Pradesh along with Yak, Gaur and Buffalo in mountain terrains at 1000-3000 Meters [1]. It is heavily built, muscular, strong and compact bovine. It is also named as 'Goyal' somewhat match with 'Gaayi' in Marathi language meaning cow. Some authors named it as 'Cattle of Mountain'. It may be called under new term as 'Boss of Indian cattle'. There is no doubt it is pride animal model in North East (NE) India [2].

Mithun is a hybrid of Wild Gaur (Bison) and domestic cattle Bos indicus [3]. Similar to its hybrid morpho-metric features appear in 
it as strong built up of body similar to Bison and people friendly behavior like domesticated Bos indicus. It also show milking characters. Though it is not famous as dairy animal but its delicious meat of tender quality is most cherished by the local tribal people and is a part of party and main food during various religious, social, cultural and festive occasions and ceremonies [4]. There are various reports on the utility, behavior and morphology of Mithun as most useful Bovine for North-East region but there are no concrete suggestions and plans have been explained by the scientific community. The research component has not been implemented in real practical sense for the dependent tribal population in the region. Therefore, the cattle farms or Mithun farms are remained as only demonstration models instead of extension of idea among the dependent people. Also its commercialization in terms of business has not been seriously worked out. Present study deals with suggestions on how 'Mithun' domestication may be much popularized in its distributional range. The possible factors affecting in positive and negative sense on this issue also discussed. All these aspects are reviewed and some inputs by recent observations are included.

\section{Materials and Methods}

To determine the fact that, why the domestication of 'Mithun' is not much popularized in the cities and tribal belts of Arunachal Pradesh in special there appear several articles published on 'Mithun' for its biology, ecology, behavior were reviewed and to find out the facts a field trip was conducted during end of monsoon in year 2017 in parts of Arunachal Pradesh. Formal structured and semi-structured interviews of local people were conducted to gather the information. Based on the information some models and suggestions for development of Mithun Husbandry are suggested as concrete measures, instead of its free range rearing or partial domestication.

\section{Results and Discussion}

The review of literature on Mithun subspecies, their diversity and distribution states that there are four subspecies of Mithun at present, in four different North East States of India [5], in Arunachal Pradesh (Bos frontalis arunachalee), in Nagaland (Bos frontalis nagami), in Manipur (Bos frontalis Manipuri) and (Bos frontalis mizorami) in Mizoram. This distributional range and potential of success of Mithun being a hybrid bovine to become a high chance of being converting it from semi-domestication rearing to domesticated planned Mithun Husbandry under a planned measures. In this context following are some important measures suggested to boost the Mithun Husbandry and dairy in entire North East India. It will boost economy of the local needy people. Also it may be a rich source of Meat (Beef) protein for rest of the India.

\section{Domestication of 'Mithun' as 'Mithun Husbandry': Why not? And How it is possible?}

Present population census 2012 on domesticated animals from India states that there is $23.36 \%$ increase in Mithun population in North East India. Since earlier census in 2007, which is not sufficient by considering the food, weather and other favorable conditions readily available for this bovine in the state [6]. The fact therefore suggests promoting the complete domestication of Mithun instead of its partial domestication. The residents of Arunachal Pradesh that mostly includes tribal communities have not remained till today as tribal. The education, communication and steps of National development through various development and upliftment schemes reached to the people of North East India and Arunachal Pradesh in special. Hence the people just remain as tribal with their origin but now they all (Nearly all) are in mainstream of India. Still today the question remained unanswered that why not full domestication of Mithun? The part of answer is in the present attitude of the concerned people. Though Mithun is freely available without investment in its husbandry then why will people go for taking efforts on its domestication? This attitude need to be changed and Mithun should be considered as National Property and there should be initiative at Government level for proper sustainable utilization of existing potential of this wonder animal. Important is, it can feed and fed up on variety og grass, fallen or shed off leaves of trees, or it is multi-feeder [7]. The dumped or unutilized forest fodder from $61.5 \%$ total geographical area in six different kinds of forest will be effectively utilized [8].

The belief of researchers that the Mithun as a hybrid animal get established around 8000 years ago [9] but since then till today it is in semi-domesticated state of rearing. Another point of answer lies in the lethargy of people, lack of planning to utilize the available natural resource; it is in fact a serious concern over national development and indirect prevention of entry of intellectuals and the people with business idea in the state. Hence the Government of Arunachal Pradesh have to take concrete measures first on the regular biannual Census of Mithun population and distribution instead of annual to promote or to take direct Governmental initiatives to open and operate the Mithun Husbandry as Government agro-forest based Industry. This is possible if decided by the people and the Government of North East States. The answer we get from the people and tribal through their interviews in the region clearly reflects, they are using Mithun as a natural resource which is readily available around their households and in the jungles behind their home. In fact it is nearly equal to use of wild animal for our benefits by claiming the rights of ownership on the Mithuns' which come to nearby area of village or a town. It also reveals that just by providing the handful of salt and the cattle supplement the local people claim ownership right on the existing population of Mithun. This will never solve our question and to fulfill our dream to get more meat, more leather, more milk, bones, and manure from Mithun. Though it is a State animal of Arunachal Pradesh and got the place on 'seal' of Nagaland State Government, but it is still literally a wild or stray animal so called under Semi-domestication. Hence there should be special efforts to develop 'Mithun Husbandry through the direct involvement of Arunachal Pradesh Government Animal Husbandry department or through private investors. This will boost the economy of the state in multifold. It will give employment for the locals or for the people of India. The demand of tender meat of Mithun in the State 
is now limited only during ceremonial occasions may be a regularly available meat. The same would be processed and developed in to several products and byproducts exported to earn foreign exchange also. It is an educational and research backwardness that the Mithun is distributed in entire North East but only one Institution with few staff members is working in Nagaland ' ICAR National Research Institute on Mithun'. With limitations this is working on very few issues hence there must be several Departments, Industries related to education, research and utilization of Mithun as a Natural resource in sustainable way for the development of NE India. IUCN (1980) [10] is of opinion that there may be behavioural change and chance of failure of captive husbandry of Mithun but there are various methods of cattle rearing like open area with shade and fencing, tied at night, milking and care, One-way feeder and shelter, two way feeder and shelter. From these methods when we pass several generations of this breed then it will adapt and will start to survive as domesticated animal. No doubt there are chances of loss of some wild behavioural aspects in this species but what we lose will be very little than what we gain in Mithun Animal Husbandry development.

\section{Mithun as a Tender Meat Ball But Prevent Brutal Killing and Go for Scientific Sacrifice}

The biochemical and nutritional composition of meat of Mithun has been investigated by several researchers that the Mithun Beef has good quality proteins and non-deposible fats as a superior quality meat than any other cattle; moreover, the Mithun meat is tender, tasty and delicious as compared to other cattle next to Pork $[9,11]$ in terms of its quality. Single Mithun when sacrificed and dressed (removal of non-edible visceral organs and body contents) yields about $45-60 \%$ meat of its $450-600 \mathrm{~kg}$ total body weight that goes to $200-400 \mathrm{~kg}$ beef and other tissues in edible bone marrow, liver, brain, kidneys etc. Hence to serve for large gatherings Mithun is sacrificed during marriage ceremony and festive celebrations. When the utilization of Mithun as a source of meat is analyzed then a bare fact come in front that naturally developed, semidomesticated Mithun is sacrificed bruit less way of killing under the ownership right of someone from the tribal communities, this can be changed by using the Mithun from Its special rearing sites like Mithun Husbandry Farm and sacrificing in a scientific way without any exhibition way to prevent the development of cruelty approach among the people and the young generation. This kind of activity will be cheaper than existing value of 1.00 to 1.5 lakh INR/Adult Mithun as its market price. It is one of the wealth commodities in North East [12] and still it has been traditionally offered to bride side to fix the marriages in Tribal communities of Arunachal Pradesh and Nagaland. The flurishment of Mithun husbandry will make it cheap and easy for common man. It will also increase the industrial development on meat processing, packaging for local use and export within India and abroad.

\section{Importance of Artificial Insemination (ai) in Mithun Husbandry Development}

The Mithun has good reproduction vigor as it show breeding throughout year and on an average it starts breeding at the age of
27-36 months, bull starts for active breeding by mating to females in heat at the age of 3-4 years [9]. In a heard of 10 female one bull is sufficient (10:1). Such kind of naturally occurring breeding heard is reported by the local tribal communities. At close to parturition the owners bring the pregnant Mithun female to their home for very short period and rest of the period it has been left as wild, by wandering around the villages. Major States in North East are not famous for agriculture produce hence no damage to crop from the Mithun. It is one of the positive factors to initiate the Mithun Husbandry. There should be semen collection and dilution centre for a Mithun Farm where the special high quality Mithun bulls may be specially reared for semen collection purpose only. Such centers may be established at least one in each district or at specially identified areas in the N. E. states subject to easy access by roads for faster distribution to AI sites. The diluted semen may be preserved in plastic straws under the cryo-preservation [13] in liquid nitrogen, from where the semen straws may be transported to Mithun Husbandry farms for AI to females in heat. In this case there is no need to maintain a Bull at the farm centre. This will be an effective way to propagate this wonder hill animal as it is a routine process for AI to cattle in other parts of India. This will be an important issue in breeding management. It is hidden and untamed potential of North East region.

\section{Mithun Leather and Goods as Industry}

Mithun leather will be an important byproduct from large scale Mithun Husbandry development. Naturally due to hybrid nature of animal both the features from wild Bison and domestic Bos species appear in the Mithun skin. The leather of Mithun is therefore superior then regular cattle leather. The hide size obtained after dressing is also quite large up to 7-8 M2 /animal. The flexibility of processed leather is high hence folding during preparation of various goods do not damage or cut the leather. There will be a separate industry cum research Institute for the processing of Mithun leather and preparation of goods useful specially in defense sector especially to prepare quality shoes, jackets and other essentials to defend the harsh cold of North East Border line area for Indian troops [14].

\section{Milk and Products from Mithun}

It has been reported that, milk of Mithun is of high quality in terms of its good quality proteins and fat. The milk proteins are $5-7 \%$ and Fat $\%$ is $8-13 \%$ of that solid not fat is $18-24 \%$. These nutritional contents are of high standard in terms of nutritional value. Naturally the Mithun female produce less amount of milk (1.0-1.5 Lit/Milking attempt/day). On an average of its milking period it produce 250-300 lit. of milk. It indicates that the Mithun is not famous for milk and it is naturally low milk producing animal. But the positive aspect is when it will be domesticated then collective milk production through Mithun Husbandry process with special dietary supplement the milk production will increase.

There appears the natural development of hybrids between strains from Arunachal Pradesh, Mizoram, Nagaland and Manipur as a slow process (Figures 1-4) but by identifying the milking 
traits and hybridizing with genome of high milking Bos indicus strain in other states of India like Sahewal, Lal kandhari, Sindhi etc. there may be improvement in milk yield in Mithun or there is need of rigorous research on composition of milk by quantitative and qualitative methods to identify the superiority. ICAR-National Centre for Mithun, Nagaland has identified the milk production potential and prepared the milk products and byproducts like Barphi, Paneer, Curd, Cheese etc. Now the need of time is instead of importing the milk to North East from Gujrat, Haryana, Andhra Pradesh, Punjab or other dairy developed states in India. All North East states especially Arunachal Pradesh should be self-reliant on commercial scale. On Government level or under the co-operative process it is possible. We don't find milk venders who distribute milk to houses as a common early morning scene in major parts of developed states like Punjab, Gujrat, Maharashtra, Uttar Pradesh. This is possible in North East also. Another high possibility is to pack, process and distribute the milk and milk products. Most remarkable factor in Arunachal is, here we found grass and forest fodder almost throughout year but it remains unutilized. Only $2 \%$ of cattle fodder is utilized from the available. On experimental basis there is opportunity to introduce the cattle breeds of similar quality from other states of India which can withstand in the North East conditions. The available literature does not show any such experiment has been done in the region. This will boost for dairy development in the region.

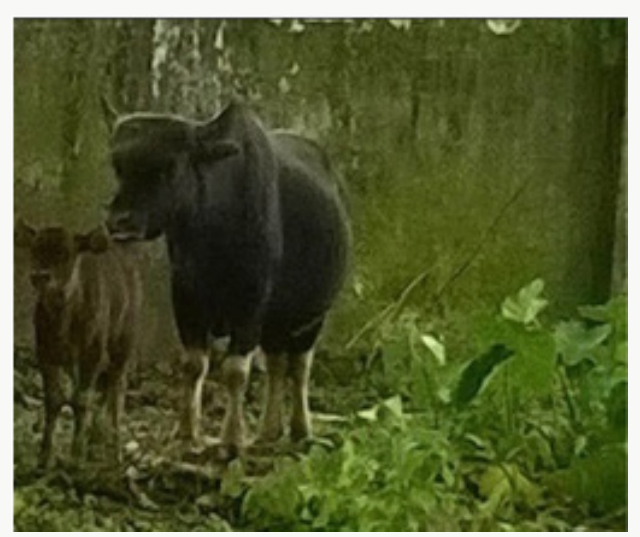

Figure 1: Bos frontalis nagami (Mithun) Female with Calf.

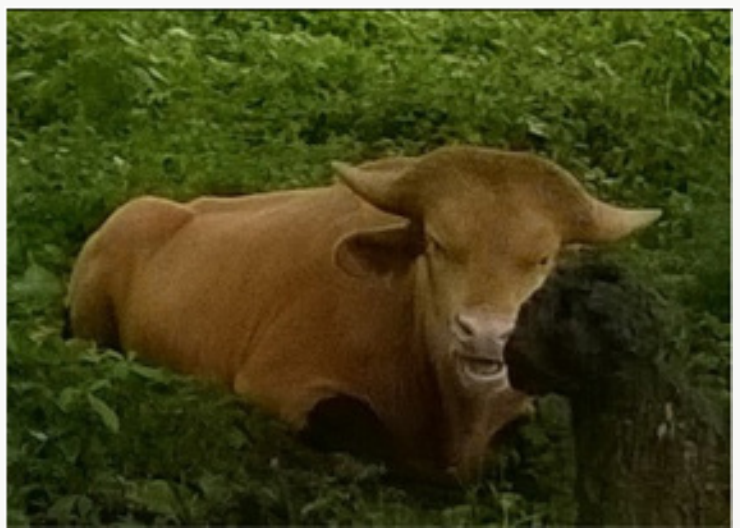

Figure 2: Bos frontalis arunachali (Mithun) Male resting for rumination.

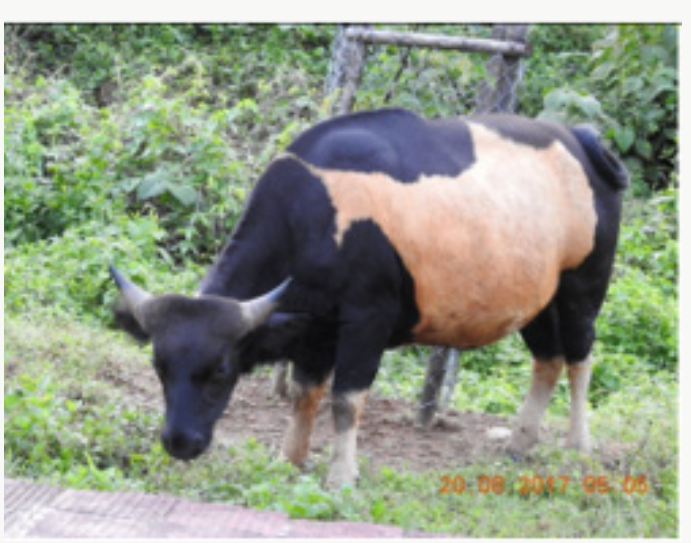

Figure 3: Bos frontalis (Mithun) Female (Hybrid of Arunachali and Mizorami strains).

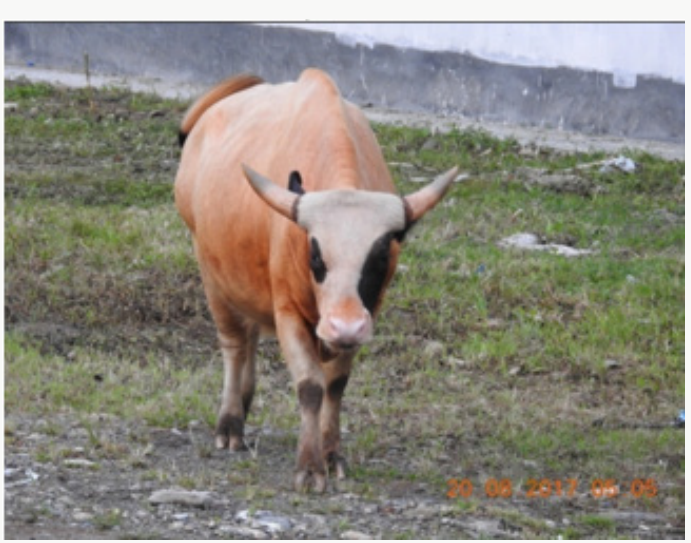

Figure 4: Bos frontalis arunachali (Mithun) free wandering Male.

\section{Conclusion}

Mithun (Bos frontalis) the Boss of Cattle has high potential to become key animal to increase the meat production, to develop leather industry and to self-reliant on milk and milk products for the people of North East Indian states. It may be carried to other states of India to get more meat of tender quality. The Mithun is one of the untamed potentials remain dumped, that need to be utilized in scientific and sustainable way before its slow and steady extinction from the region.

\section{Acknowledgement}

Thanks to Centre with Potential for Excellence in Biodiversity, Rajiv Gandhi University, Itanagar, Arunachal Pradesh for providing the opportunity and financial arrangements to stay in the study area to one of the author S. P Chavan under CPEB-II Phase Grants from UGC New Delhi.

\section{References}

1. Arora C (1998) Less used animal: Yak and Mithun- an overview. Indian Journal of Animal Science 68: 775-742.

2. Shisode MG, Khanvilkar AV, Kulkarni MD, Samant SR, Yadav GB, et al. (2009) Mithun: The pride animal of North Eastern hilly region of India. Veterinary World 2(12): 480-481. 
3. Gupta N, Gupta SC, Verma ND, Pundir RK, Joshi BK, Nivsarkar AE, Sahai R (1996) Mithun: An Important Bovine species of Indian origin. Animal Genetic Resources Information Bulletin 18: 41-48.

4. Simoons FJ, Simoons ES (1968) A ceremonial ox of India. The Mmithun in nature, culture and history. The University of Wisconsin Press, Madison.

5. Bhushan S, Sharma D, Bujarbaruah KM, Singh RV (2000) Annual Report, National Research Centre on Mithun, Jharnapani, Nagaland 797106: 4-10.

6. Arunachal Pradesh Statistical abstract (APSA) (2013) Directorate of Economics and Statistics. Itanagar.

7. Das KC, Prakash B and Rajkhowa C (2008) Nutrition and feeding of Mithun (Bos frontalis) in hill livestock farming system. Indian Journal of Animal Nutrition 25(1): 1-10.

8. FSI (2009) State Forest Report, Forest Survey of India. Ministry of Environment and Forest, Kauhgarh Road, Dehra Dun.
9. Mondal M, Baruah KK, Rajkhowa C (2014) Mithun: An animal of Indian pride. Live Stock Research for Rural Development 26(1).

10. International Union for the Conservation Nature (1980) World conservation Strategy.

11. Mondal M, Dhali A, Rajkhowa C, Prakash BS (2004) Secretion patterns Growth Hormone in growing captive Mithun (Bos frontalis). Zoological Science 21: 1125-1129.

12. Moyong $O$ (2012) Commoditization and sustainable management of Mithun (Bos frontalis) in Arunachal Pradesh (North East India). IOSR Journal of Agriculture and Veterinary Science 1(3): 39-43.

13. Mondal M, Karunakaran M, Lee K, Rajkhowa C (2010) Characterization of Mithun (Bos frontalis) ejaculate and fertility of cryopreserved sperm. Animal Reproduction Science 118(2-4): 210-216.

14. International Union for Conservation of Nature and natural Resources Gland, Switzerland.
This work is licensed under Creative Commons Attribution 4.0 License

Submission Link:

Submit Article

DOI: $10.32474 /$ CDVS.2018.01.000122

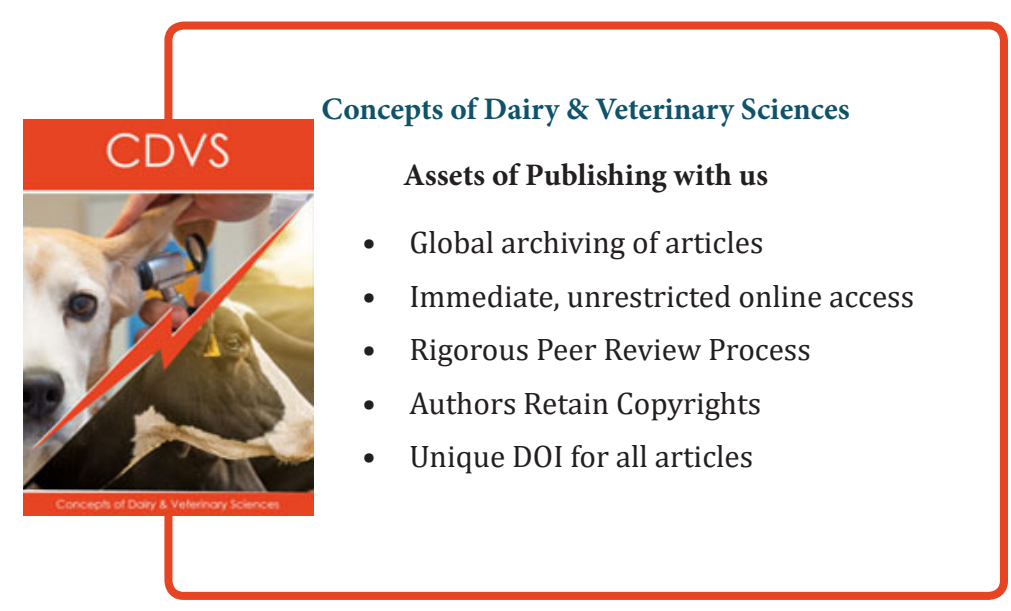

